agriTECH, 41 (1) 2021, 25-33

\title{
Fatty Acid Composition of Cocoa Beans from Yogyakarta Special Region for the Establishment of Geographical Origin Discriminations
}

\author{
Retno Utami Hatmi ${ }^{1}$, Makhmudun Ainuri ${ }^{2}$, Anggoro Cahyo Sukartiko ${ }^{2 *}$ \\ ${ }^{1}$ Yogyakarta Assessment Institute for Agricultural Technology, Jl. Stadion Maguwoharjo No. 22 Wedomartani, \\ Ngemplak, Sleman, Yogyakarta, Indonesia \\ ${ }^{2}$ Department of Agro-Industrial Technology, Faculty of Agricultural Technology, Universitas Gadjah Mada, \\ Jl. Flora No. 1, Bulaksumur, Yogyakarta 55281, Indonesia \\ *Corresponding author: Anggoro Cahyo Sukartiko, Email: cahyos@ugm.ac.id
}

Submission:April 1, 2020; Revision: June 29, 2020; Acceptance: July 3, 2020

\begin{abstract}
The composition of fatty acids in cocoa beans, which affect the characteristics of the processed products, is dependent on the geographic location. This research aimed to identify the fatty acid composition of cocoa beans from the Special Region of Yogyakarta (Patuk Gunungkidul and Kalibawang Kulon Progo), used as a geographical origin discrimination parameter. The data were analyzed using ANOVA and Partial Least Square - Discriminant Analysis (PLS-DA). The results showed that the average composition from Patuk Gunungkidul and Kalibawang Kulon Progo were dominated by stearic $(35.23 \%)$, oleic $(33.12 \%)$, and palmitate acids $(27 \%)$. The three unsaturated fatty acids (palmitoleic, oleic, and linolenic acids) were significantly different in some origin regions of the cocoa bean sample, while the three types of saturated fatty acids (capric, caprylic, and lauric acids) were distinguishing factors due to their minimal availability in nature, as they were not detected in all regions. The developed method combined with PLS-DA was successfully employed the fatty acid composition to discriminate the geographic origin of cocoa beans in the Special Region of Yogyakarta.
\end{abstract}

Keywords: Cocoa bean; discriminant analysis; fatty acid; geographical origin; partial least square

\section{INTRODUCTION}

Fat is the main component of cocoa, which possesses the highest economic value compared to the other derivative products with an export value of 6.3 US \$ per kilogram in 2015 (Directorate General of Estate Crops, 2016). The availability of fat in fermented cocoa beans for five days ranges between 43.18 and $58.40 \%$ of all its components (Jonfia-Essien and Tettey, 2016). Cocoa fat is an essential factor in the process of making chocolate, as it determines the rheology, texture, and chemical characteristics of chocolate products (Lipp and Anklam, 1998). Furthermore, the physical and thermal properties of cocoa fat are determined by the fatty acid type, as well as the position and distribution of the Triacylglyceride (TAG) molecule (Aronhime and Garti, 1988) in (Isyanti et al., 2015).
Fatty acids are a group of hydrocarbon compounds that contain long-chain, carboxylic groups at the ends. Based on their types of bonds, these acids are grouped into two, namely saturated and unsaturated fatty acids. The saturated have a single carbon atomic bond, including fatty acid caprylate (C8: 0$)$, caprate (C10: 0$)$, lauric (C12: 0$)$, myristate (C14: 0$)$, palmitate (C16: 0$)$, stearic (C18: 0), and arachidic (C20: 0). In contrast, unsaturated fatty acids, such as palmitoleic (C16: 1 ), oleic (C18: 1), linoleic (C18: 2), and linolenic fatty acids (C18: 3), possess at least one double carbon bond.

The dominant types of fatty acids in cocoa beans are palmitic, stearic, and oleic acids (Ristanti et al., 2016; Torres-Moreno et al., 2015; Vieira et al., 2015) with levels $>25 \%$ (palmitate), $>33 \%$ (stearic), and> 34\% (oleate) (Torres-Moreno et al., 2015). Additionally, Triacylglycerol (TAG) composition in cocoa butter is 
responsible for the physical properties of processed cocoa products, such as shiny appearance, hardness or ease of melting, and taste (Sirbu et al., 2018; Marty-Terrade and Marangoni, 2012). The dominant triglycerides found in cocoa fat include 1,3 dipalmitin2-oleate glycerol (POP), 1-palmito, 2-olein, 3-stearin glycerol (POS), and 1,3 distearin-2-oleate glycerol (SOS) (Lipp and Anklam, 1998). The length of the short carbon chain, the level of saturation of fatty acids, and the free fatty acid content significantly influence the hardness/ melting point of cocoa fat (Guehi et al., 2008). High saturated fatty acids with short carbon chains result in a low melting point of the chocolate product (Tarigan et al., 2016).

The composition of cocoa bean varies according to their geographical origin (Torres-Moreno et al., 2015). Extrinsic factors aside geographical origin, which significantly influence the composition and physicochemistry of cocoa fatty acids in Brazil include climate conditions, harvest time, and farming methods (Vieira et al., 2015). According to Liyanda et al. (2012) and Alam et al. (2010) cocoa plants are highly susceptible to the elevation level of the place of growth, as the temperature atcertain altitudes influencetheoptimization of the metabolic process of cocoa beans. The altitude of the growing area also affects several things, including production and fat content. Furthermore, Tresniawati et al. (2014) observed an interaction between the fat quality of cocoa beans and the altitude of growth from above sea level. Altitude is one of the characteristics of the land, which has a significant negative correlation with cocoa production and a positive correlation with fat content. A higher location will result in a decrease in production, alongside an increase in fat content (Liyanda et al., 2012). Therefore, a higher location of growing cocoa plants causes an increased seed size and fat content. This agrees with Minifie (1989), which stated that higher fat content are obtained from more giant-sized cocoa beans.

Liendo et al. (1997) stated that the composition of cocoa beans varies according to geographical origin. The fatty acid profiles and the amount of cocoa fat in chocolate products depend on the conditions of growing cocoa plants. Furthermore, Lipp and Anklam (1998) mentioned that the geographical origin influences the composition of cocoa fatty acids. The palmitic, stearic, and mono-unsaturated acid triacylglycerol increases with increasing environmental temperature, while high rainfall affects the levels of stearic, oleic, and free fatty acids (Lehrian et al., 1980); Mustiga et al. (2019). Fowler (2009) confirmed that the fat content and melting characteristics of cocoa beans are strongly influenced by the type of cocoa plants and environmental conditions, precisely the average daily temperature during the last few months. This environmental temperature affects the hardness of cocoa butter; the lower the environmental temperature, the softer the butter, alongside a lower melting point.

According to Foubert et al. (2004), differences in the composition of cocoa fatty acids cause differences in crystallization kinetics. Mono-unsaturated fatty acids, or oleic acids (C18:1) and polyunsaturated fatty acids (linoleic acid and linolenic acid) (C18:2 and C18:3) significantly affect the crystallization of cocoa butter (Marty-Terrade and Marangoni, 2012). In addition, cocoa fat is dominated by components of saturated fatty acids (palmitic and stearic) and unsaturated fatty acids (oleic, linoleate, and linoleate). Saturated fatty acids have a significantly higher melting point than the unsaturated (palmitic acid $=62^{\circ} \mathrm{C}$ and stearic acid $=68$ ${ }^{\circ} \mathrm{C}$; while oleic acid $=160^{\circ} \mathrm{C}$ ) (Tymoczko et al., 2015). This difference in melting point causes a hard or solid texture in chocolate products at room temperature and melts when placed in the mouth (McHenry et al., 1987).

Apart from its intrinsic quality, the geographical origin of cocoa beans is one of the extrinsic factors which promote consumer confidence (Saltini et al., 2013) and support sustainable production, especially with the discovery of markers to verify the authenticity (Acierno et al., 2016). Therefore, one of the cocoa-producing regions in Indonesia, the Special Region of Yogyakarta, can use these factors to increase consumer acceptance, providing added value to the processed products. This study aimed to identify the fatty acid composition of cocoa beans as a distinguishing parameter for their geographical origin, derived from three levels of elevation in the Patuk Gunungkidul and Kalibawang Kulon Progo, Special Region of Yogyakarta.

\section{MATERIALS AND METHODS}

\section{Sample}

The sampling technique refers to the modified study by (Bertoldi et al., 2016) adjusted to the research needs. Samples were obtained through stratified and simple random sampling. The stratified sampling was used to distinguish the elevation level of cocoa plantsuitable lands into three groups, i.e., 0-300 m asl, 301$450 \mathrm{~m}$ asl, and $450 \mathrm{~m}$ asl, respectively (Directorate General of Estate Crops, 2014), while simple random sampling was used for selecting the cocoa pod trees. As a dominant cocoa variety, bulk cocoa (lindak) was selected as a default sample in this study.

The primary samples of the study were cocoa pods taken from the Patuk Gunungkidul and Kalibawang 
Table 1. Coordinate and elevation of the sample's origin location

\begin{tabular}{|c|c|c|c|c|c|}
\hline $\begin{array}{l}\text { Elevation } \\
\text { (m asl) }\end{array}$ & $\begin{array}{l}\text { Area } \\
\text { codes }\end{array}$ & Sample's Origin & $\begin{array}{c}\text { Coordinates } \\
\text { Latitude (S), Longitude (E) }\end{array}$ & $\begin{array}{c}\text { Elevation } \\
\text { Range } \\
\text { (m asl) }\end{array}$ & $\begin{array}{l}\text { Number of } \\
\text { pod samples }\end{array}$ \\
\hline \multirow[t]{2}{*}{$0-300$} & GK1 & Patuk (Nglanggeran, Bunder, Putat) & $\begin{array}{l}7^{\circ} 51^{\prime}-7^{\circ} 52^{\prime} \mathrm{S} ; \\
110^{\circ} 30^{\prime}-110^{\circ} 32^{\prime} \mathrm{E}\end{array}$ & $130-267$ & 40 \\
\hline & KP1 & Kalibawang (Banjaroya, Banjarharjo) & $\begin{array}{l}7^{\circ} 39^{\prime}-7^{\circ} 41^{\prime} \mathrm{S} ; \\
110^{\circ} 14^{\prime}-110^{\circ} 15^{\prime} \mathrm{E}\end{array}$ & $173-261$ & 40 \\
\hline \multirow[t]{2}{*}{$301-450$} & GK2 & Patuk (Ngoro-Oro, Putat, Nglanggeran) & $\begin{array}{l}7^{\circ} 50^{\prime}-7^{\circ} 51^{\prime} \mathrm{S} ; \\
110^{\circ} 30^{\prime}-110^{\circ} 33^{\prime} \mathrm{E}\end{array}$ & $302-401$ & 40 \\
\hline & $\mathrm{KP} 2$ & Kalibawang (Banjaroya, Banjarharjo) & $\begin{array}{l}7^{\circ} 39^{\prime}-7^{\circ} 41^{\prime} \mathrm{S} ; \\
110^{\circ} 13^{\prime}-110^{\circ} 14^{\prime} \mathrm{E}\end{array}$ & $302-449$ & 40 \\
\hline \multirow[t]{2}{*}{$>450$} & GK3 & Patuk (Nglegi) & $\begin{array}{l}7^{\circ} 50^{\prime}-7^{\circ} 51^{\prime} \mathrm{S} ; \\
110^{\circ} 33^{\prime}-110^{\circ} 33^{\prime} \mathrm{E}\end{array}$ & $469-658$ & 40 \\
\hline & KP3 & Kalibawang (Banjaroya, Banjarharjo) & $\begin{array}{l}7^{\circ} 38^{\prime}-7^{\circ} 39^{\prime} \mathrm{S} ; \\
110^{\circ} 12^{\prime}-110^{\circ} 13^{\prime} \mathrm{E}\end{array}$ & $477-559$ & 40 \\
\hline
\end{tabular}

Kulon Progo, each with three levels of altitude (0-300 $\mathrm{m}$ asl, 301-450 $\mathrm{m}$ asl, and $450 \mathrm{~m}$ asl). Area codes were given for each combination of area and altitude, with GK and KP showing the Gunungkidul and Kulon Progo areas, respectively. Simultaneously, 1, 2, and 3 indicate an altitude range of 0-300 $\mathrm{m}$ asl, 301-450 $\mathrm{m}$ asl, and $>450 \mathrm{~m}$ asl, respectively. For example, GK1 showed the Gunung Kidul region at an altitude of 0-300 m asl, while KP2 showed the Kulon Progo region at an altitude of 301-450 m asl. For each combination of area and altitude, twenty cocoa trees were randomly selected, and two cocoa pods were obtained from each tree. Therefore, a total of forty cocoa pods were obtained for each combination of area and altitude. The total number collected for the whole GK1, GK2, GK3, KP1, KP2, and KP3 regions, was 240 cocoa pods. Sampling locations were distributed in detail according to villages, sub-village, coordinates, and elevation levels in both regions (Patuk Gunungkidul and Kalibawang Kulon Progo). Sample sizes obtained from each region were in line with Fraenkel et al. (2012). Furthermore, the combination of regions and altitudes, area codes, the origin of samples, coordinates, elevation ranges, and the number of cocoa pods collected are shown in Table 1 , while environmental characteristics of the location are shown in Table 2.

\section{Sample Preparation}

To represent one combination of area and altitude, forty randomly selected cocoa pods were pooled for fatty acid analysis. Therefore, there were six pooled triplicate samples, representing six combinations of areas and altitudes (GK1, GK2, GK3, KP1, KP2, and KP3), with a total of 18 samples for analysis. Sample preparation started by delaying the breakdown of cocoa pods for three days after picking for uniformity of maturity and minimizing pulp, the pod was broken down, and its seed was taken. Afterward, wet cocoa beans from each pod were dried separately in a solar drying container for 7-10 days (7 hours per day). Samples of dried cocoa beans were then used for the analysis of fatty acids. Each sample was stripped, with the nibs and skin weighed, and smoothed using a mortar to pass the 40mesh sieve.

\section{Sample Analysis}

Each cocoa bean powder sample was weighed $50 \mathrm{~g}$ during fatty acid analysis, which was performed with Gas Chromatography (GC) according to (Park and Goins, 1994). The GC used was the Shimadzu brand, type GC 2010 Plus. Fatty acids were obtained from cocoa bean powder samples, placed in a test tube, and diluted with $100 \mu \mathrm{l}$ of methyl chloride and $1000 \mu \mathrm{l}$ of $\mathrm{NaOH} 0.5 \mathrm{~N}$ in methanol. Furthermore, nitrogen gas $\left(\mathrm{N}_{2}\right)$ was inserted into the reaction tube and closed tightly to remove oxygen. The test tube was then heated in a water bath at $88-90{ }^{\circ} \mathrm{C}$ for $10 \mathrm{~min}$ and cooled, with an addition of $1000 \mu \mathrm{BF}_{3} 20 \%$ methanol. Nitrogen $\left(\mathrm{N}_{2}\right)$ gas was added to the test tube, closed tightly, and reheated with Waterbath at the same temperature and time. Afterward, the test tube was cooled at room temperature, with the addition of $1000 \mu \mathrm{l}$ of distilled water and $1000 \mu$ of hexane, further exported for $1 \mathrm{~min}$ to extract fatty acid methyl esters. The test tube was centrifuged for 10 min until the top layer formed was ready for analysis using GC.

The operational conditions of gas chromatography during fatty acid analysis were set as follows: using a 
Flame Ionization Detector (FID) type at $240{ }^{\circ} \mathrm{C}, 240$ ${ }^{\circ} \mathrm{C}$ injector temperature, RTX-Wax column dimension 30 meters long and $0.25 \mathrm{~mm}$ diameter, helium as a carrier gas, the column flow velocity of $0.80 \mathrm{~mL} / \mathrm{min}$, column temperature at $150{ }^{\circ} \mathrm{C}$ was raised to $200{ }^{\circ} \mathrm{C}$ with an average increase of $8{ }^{\circ} \mathrm{C} / \mathrm{min}$ and maintenance of 220 ${ }^{\circ} \mathrm{C}$ temperature for 25 minutes. The identification of fatty acids was performed by comparing the standard fatty acid mix LC06457 Supelco C 8:0 - C 24:0.

This study used Garmin GPS map 62s series GPS for tracking pod sampling locations in the field. Several tools were used to analyze fatty acid components, including analytical balances AND FX-3000i Japan series, oven, water bath type WNB45 Memmert Germany, SHIBATA TTM-1 vortex mixer, $\mathrm{K}$ Centrifuge PLC series, and GC 2010 Plus brand Shimadzu.

\section{Statistical Analysis}

The differentiation of the geographical origin of cocoa beans was performed using ANOVA and Partial Least Square - Discriminant Analysis (PLS-DA). ANOVA was performed with SPSS Statistics Version 22 software (IBM Corporation, USA), while PLS-DA was applied with XLSTAT Basic + (Addinsoft).

\section{RESULTS AND DISCUSSION}

Gunungkidul and Kulon Progo are areas in Yogyakarta Special Region with the most significant potential for cocoa production. In Gunungkidul Regency, production mainly occurred in Patuk $(51.37 \%)$, while Kalibawang in Kulon Progo District was the largest producer $(32.77 \%)$ of cocoa in the nine sub-districts.

\section{Characteristics of the Sample Origin Location}

This study used a bulk cocoa (lindak) sample harvested from productive plants (10 to 25 years age range). Samples were obtained from smallholder plantations in the Patuk Gunungkidul and Kalibawang Kulon Progo. Cocoa plants in these two regions were not planted monoculture and did not use shade plants in their cultivation. Both regions, Gunungkidul and Kulon Progo, have different characteristics; therefore, there may be differences in the quality of cocoa beans produced. The determination of characteristics of the sample location of origin is essential for product traceability. Characteristics of sample locations, in general, can be identified according to the area, scope of the area, topography (height and slope), soil type, and climate (sun intensity, temperature, humidity, and rainfall). The general characteristics of the sample origin location are shown in Table 2.

Patuk has a larger area and village coverage compared to Kalibawang. The elevation and slope in both regions are dominated by the same class. Although there are similarities in the level of elevation and slope, a slight difference in climatic conditions in both regions exist due to the intensity of solar radiation and rainfall. Furthermore, differences in the geographical formation of these regions cause differences in the type of soil formed. Of the various kinds of soil that exist in both regions, the most suitable soil type for cocoa plant growth is latosol and regosol. In contrast, rendzina, lithosols, and grumosol are very minimal in nutrients and organic due to their formative process. They originate from weathering of large and hard rocks (lithosols), limestone (rendzina), and limestone formation. Additionally, the

Table 2. Characteristics of sample-origin location

\begin{tabular}{|c|c|c|c|}
\hline Area Parameter & Unit & $\begin{array}{c}\text { Patuk } \\
\text { Gunungkidul }\end{array}$ & $\begin{array}{l}\text { Kalibawang } \\
\text { Kulon Progo }\end{array}$ \\
\hline Area & ha & $7204^{a}$ & $5096.70^{b}$ \\
\hline Number of villages & village & $11^{a}$ & $4 \mathrm{~b}$ \\
\hline Altitude (dominance) & $\mathrm{m}$ asl & $100-499(93.02 \%)^{a}$ & $101-500(96.16 \%)^{b}$ \\
\hline Slope (dominance) & degree $\left({ }^{\circ}\right)$ & Steep >250 (64\%) a & Steep $16-400(57.19 \%)$ b \\
\hline Solar radiation & $\mathrm{W} / \mathrm{m}^{2} /$ month & $15.49-18.68^{c}$ & $19-31.63^{c}$ \\
\hline Temperature & ${ }^{\circ} \mathrm{C}$ & $25.24-26.01^{c}$ & $26.23-26.5^{c}$ \\
\hline Humidity & $\%$ & $82.60-98.31^{c}$ & $81.84-85.97 c$ \\
\hline Rainfall & $\mathrm{mm} /$ year & $2348-3127^{c}$ & $3709-3887^{c}$ \\
\hline Soil type & - & $\begin{array}{c}\text { Red Latosol - Lithosols; } \\
\text { Lithosols; Lithosols - }^{\text {Rendzina d }}\end{array}$ & Latosol, Grumosol, Regosol \\
\hline
\end{tabular}

Note: (a) BPS Gunungkidul (2016); (b) BPS Kulon Progo (2016); (c) BMKG Special Region of Yogyakarta (2017); (d) Bakosurtanal (2011); (e) BP3K Kalibawang (2016) 
identification of the sampling location was also carried out in detail, covering the village area, coordinates, and elevation in this study for both the Patuk Gunungkidul region and Kalibawang Kulon Progo (Table 1).

The differences in land and climate characteristics in both regions caused corresponding differences in some quality parameters of cocoa beans, including seed sizes (physical) and their nutritional content (fatty acids). This result agrees with (Torres-Moreno et al., 2015), which stated that the amount of cocoa fat and fatty acid composition in chocolate products rely on the growth conditions of the cocoa plant which gives different physical properties, thereby influencing the processing and texture of the final product.

\section{Fat Composition and Geographical Origin Discrimination}

The determination of the composition of cocoa bean fatty acids originating from two regions with different land and climate conditions at three altitude levels is essential. It helps to ascertain the advantages of each cocoa bean product, to enhance precise use and processing techniques. Cocoa fat is an essential factor in the manufacture of chocolate as it determines the rheology, texture, and chemical characteristics of chocolate products (Lipp and Anklam, 1998). The physical and thermal properties of cocoa fat are determined by the fatty acid type and the distribution or position of the Triacylglyceride (TAG) molecule (Aronhime and Garti, 1988) in (Isyanti et al., 2015). Meanwhile, the dominance of components and proportions of fatty acids in different countries and regions vary. Cocoa beans from the Special Region of Yogyakarta (both from the Patuk Gunungkidul and Kalibawang Kulon Progo regions) were dominated by fatty acid components, with the largest portion being stearic acid, with an insignificant average value of $35.227 \%$. This was followed by oleic at $33.121 \%$ and palmitic at $27 \%$, as shown in Table 3 . The composition and proportion of these main fatty acids of cocoa beans (stearic, oleic, and palmitic) from the Special Region of Yogyakarta possesses similarities with cacao beans originating from Ecuador, Ghana, Togo (West Africa), Brazil, and Venezuela with stearic acid levels $(33.76 \% ; 36.34 \% ; 35.81 \% ; 33.96 \% ; 35.93 \%)$, oleic (34.73\%; 34.31\%; 33.74\%; 33.84\%; 36.55\%), and palmitate $(27.61 \% ; 25.02 \% ; 26.24 \% ; 26.53 \%$; $26.13 \%$ ) respectively (Liendo et al., 1997; TorresMoreno et al., 2015; Vieira et al., 2015; Zyzelewicz et al., 2014). Meanwhile, Ristanti et al. (2016) analyzed cocoa beans from Sulawesi, and concluded that the

Table 3. Fatty acid composition

\begin{tabular}{|c|c|c|c|c|c|c|c|}
\hline \multirow{2}{*}{\multicolumn{2}{|c|}{$\begin{array}{l}\text { Fatty Acid Component } \\
\qquad(\%)\end{array}$}} & \multicolumn{6}{|c|}{ Origin } \\
\hline & & \multirow{2}{*}{$\frac{\text { GK1 }}{0.096 \pm 0.090}$} & \multirow{2}{*}{$\frac{\mathrm{GK} 2}{0.024 \pm 0.022}$} & \multirow{2}{*}{$\frac{\mathrm{GK} 3}{0.024 \pm 0.042}$} & \multirow{2}{*}{$\frac{\mathrm{KP} 1}{0.016 \pm 0.028}$} & \multirow{2}{*}{$\frac{\mathrm{KP} 2}{0.000 \pm 0.000}$} & \multirow{2}{*}{$\frac{\mathrm{KP3}}{0.000 \pm 0.000}$} \\
\hline Caprylic & $C 8: 0$ & & & & & & \\
\hline Capric & C $10: 0$ & $0.044 \pm 0.041$ & $0.000 \pm 0.000$ & $0.018 \pm 0.031$ & $0.000 \pm 0.000$ & $0.000 \pm 0.000$ & $0.000 \pm 0.000$ \\
\hline Lauric & C $12: 0$ & $0.036 \pm 0.031$ & $0.000 \pm 0.000$ & $0.183 \pm 0.317$ & $0.037 \pm 0.064$ & $0.036 \pm 0.062$ & $0.035 \pm 0.060$ \\
\hline Myristic & C $14: 0$ & $0.154 \pm 0.050$ & $0.101 \pm 0.025$ & $0.212 \pm 0.167$ & $0.129 \pm 0.043$ & $0.168 \pm 0.089$ & $0.124 \pm 0.038$ \\
\hline Palmitic & C $16: 0$ & $27.922 \pm 1.500$ & $25.665 \pm 0.277$ & $26.202 \pm 2.179$ & $27.744 \pm 0.808$ & $27.547 \pm 2.480$ & $26.916 \pm 2.609$ \\
\hline Palmitoleic & C $16: 1$ & $0.300^{\mathrm{b}} \pm 0.045$ & $0.230^{\mathrm{ab}} \pm 0.021$ & $0.194^{a} \pm 0.050$ & $0.245^{\mathrm{ab}} \pm 0.023$ & $0.279^{\mathrm{ab}} \pm 0.039$ & $0.223^{\mathrm{ab}} \pm 0.029$ \\
\hline Stearic & C $18: 0$ & $34.554 \pm 1.806$ & $36.004 \pm 0.146$ & $36.235 \pm 2.537$ & $34.763 \pm 1.032$ & $34.995 \pm 2.757$ & $34.809 \pm 0.920$ \\
\hline Oleic & C $18: 1$ & $32.368^{\mathrm{a}} \pm 0.401$ & $33.886^{b} \pm 0.428$ & $32.838^{\mathrm{ab}} \pm 0.276$ & $33.029^{a b} \pm 0.576$ & $32.960^{\mathrm{ab}} \pm 0.644$ & $33.647^{a b} \pm 0.504$ \\
\hline Linoleic & C $18: 2$ & $3.411 \pm 0.768$ & $3.050 \pm 0.171$ & $3.070 \pm 0.099$ & $2.869 \pm 0.301$ & $2.855 \pm 0.386$ & $3.173 \pm 0.153$ \\
\hline Linolenic & C $18: 3$ & $0.222^{b} \pm 0.016$ & $0.191^{\mathrm{ab}} \pm 0.011$ & $0.180^{\mathrm{ab}} \pm 0.004$ & $0.197^{\mathrm{ab}} \pm 0.040$ & $0.170^{\mathrm{ab}} \pm 0.013$ & $0.162^{\mathrm{a}} \pm 0.008$ \\
\hline Arachidic & C 20:0 & $0.894 \pm 0.041$ & $0.849 \pm 0.008$ & $0.844 \pm 0.069$ & $0.971 \pm 0.076$ & $0.990 \pm 0.162$ & $0.911 \pm 0.104$ \\
\hline \multicolumn{2}{|c|}{ SFA } & 63.700 & 62.643 & 63.718 & 63.661 & 63.736 & 62.794 \\
\hline \multicolumn{2}{|c|}{ MUFA } & $32.668^{a}$ & $34.117^{\mathrm{b}}$ & $33.032^{\mathrm{ab}}$ & $33.274^{\mathrm{ab}}$ & $33.239^{\mathrm{ab}}$ & $33.869^{\mathrm{ab}}$ \\
\hline \multicolumn{2}{|c|}{ PUFA } & 3.633 & 3.241 & 3.250 & 3.066 & 3.025 & 3.335 \\
\hline \multicolumn{2}{|c|}{ UFA } & 36.301 & 37.358 & 36.282 & 36.340 & 36.264 & 37.204 \\
\hline \multicolumn{2}{|c|}{ S/U Ratio } & 1.755 & 1.677 & 1.756 & 1.752 & 1.758 & 1.688 \\
\hline
\end{tabular}

Different letters on the same row denote significant differences $(p<0.5)$. GK stands for Gunungkidul, while KP stands for Kulon Progo. 
dominant component of fatty acids was the same. The lower percentage was still good for stearic $(27.78 \%)$, oleic $(24.77 \%)$, and palmitic acid (20.68 \%).

The similarity in the composition of the primary fatty acids of cocoa beans from Special Region of Yogyakarta, Indonesia, with other countries such as Ecuador, Ghana, Togo, Brazil, and Venezuela may be due to the similarity in growing location latitude. This latitude ranges between $20^{\circ} \mathrm{N}$ and $20^{\circ} \mathrm{S}$ of the equator, such as South America, West Africa, and Southeast Asia (Fowler, 2009). Vieira et al. (2015) confirmed the statement of Fowler (2009) that cocoa-growing locations in Brazil possesses similar growing conditions with the ones in Indonesia, in terms of temperature conditions ranging between $23.4-27.0{ }^{\circ} \mathrm{C}$, rainfall between 1193 - $2250 \mathrm{~mm}$, and at elevations up to 284 $\mathrm{m}$. Vieira et al. (2015) also stated that similar growing conditions produce cocoa fat characteristics identical to Asian and African ones. Furthermore, the temperature is an influential growing factor for the aspects of cocoa butter. The growth temperature of cocoa plants within a $20-30{ }^{\circ} \mathrm{C}$ range will produce hard cocoa butter, while below $20^{\circ} \mathrm{C}$ produces soft cocoa butter (Marty-Terrade and Marangoni, 2012). Kongor et al. (2016) stated that the chemical composition of the soil and plant age did not significantly influence the formation of flavor precursors and the final taste quality.

Statistical analysis showed that only three components of fatty acids (palmitoleic, oleic, and linolenic acids) were significantly different in the studied areas (Table 3). These three acids were components of unsaturated fatty acids. Furthermore, the minimum availability and significant difference in some regions can be used to distinguish the geographical origin of cocoa beans. For the Patuk Gunungkidul region at an elevation of 0-300 $\mathrm{m}$ above sea level, the highest percentage of palmitoleic $(0.3 \%)$, linoleic $(0.2 \%)$ and the lowest oleic acid $(32.37 \%)$ were significantly different compared to other research areas.

There were several types of fatty acids with minor amounts that were only available in certain regions. Capric acid was a fatty acid type available in the Patuk Gunungkidul region at elevations of 0-300 m asl and above $450 \mathrm{~m}$ asl. Caprylic acid was also only available in all heights in the Patuk Gunungkidul and Kalibawang Kulon Progo regions at elevations of 0-300 m asl. The only area where no lauric fatty acids were detected was Patuk Gunungkidul at altitude $301-450 \mathrm{~m}$ asl. The availability of capric, caprylate, and laurate acids has been reported only in Patuk Gunungkidul and Kalibawang Kulon Progo areas, which enables this component to be a geographic origin identifier.
In this study, Ristanti et al. (2016) and TorresMoreno et al. (2015) detected a number of minor fatty acid components in cocoa beans from Sulawesi, Ecuador, and Ghana that were not available in the Special Region of Yogyakarta, such as pentadecanoic, heptadecanoic, eicosanoic, eicosedien-oat, behenic, tricosanoic, and lignoceric acids. However, caprylic, capric, and lauric acids were detected in the Special Region of Yogyakarta, but not found in the Sulawesi region.

The statistical results also showed that the total saturated and unsaturated fatty acids of cocoa beans in the entire Special Region of Yogyakarta were not significantly different. The value of saturated fatty acids was slightly higher with an average value of $63.136 \%$, compared to the unsaturated $(36,623 \%)$ with an average $S / U$ ratio of 1,731 . The $S / U$ ratio of the cocoa beans was classified as the highest when compared to Ghana, Ecuador, and Venezuela (1.72; 1.65; and 1.64). This ratio showed that the cocoa beans from the Special Region of Yogyakarta possess the highest composition of saturated fatty acids derived from palmitic and stearic acids.

Unsaturated fatty acids in this study were categorized into mono-unsaturated carbon bonds (MUFA) and polyunsaturated (PUFA) bonds. The MUFA were significantly different for the Patuk Gunungkidul region of $0-300 \mathrm{~m}$ asl and $301-450 \mathrm{~m}$ asl with other research areas. According to Torres-Moreno et al. (2015), PUFA has a maximum total calorie content of $10 \%$, whereas MUFA should be the main component due to its excellent hypocholesterolemic effect for health. This agrees with the results of this study, which had an average PUFA value of $3.258 \%$ and MUFA of $33.336 \%$.

The components of both saturated and unsaturated fatty acids detected in the study area include arachidic, linoleic, and linolenic acids. Arachidic acid (0.91\%) had a lower value than the Brazilian $(2.1 \%)$, while linoleic acid $(3.07 \%)$ was almost on par with cocoa butter from Brazil (3.5\%). This level was high as the average originating from Africa (Ghana and Ivory Coast) was only $2.8 \%$. Linolenic acid $(0.187 \%)$ was at the same level as a range of previous studies (0.1-0.2\%) (Zyzelewicz et al., 2014).

The differentiation of the geographical origin of cocoa bean samples using ANOVA analysis (Table 3) cannot be performed without involving a combination of the various fatty acids. Principal Component Analysis (PCA), an unsupervised multivariate technique was used initially to reduce the number of variable and to detect sample grouping. The first two factors allow us to represent $55.61 \%$ of the initial variability of the data (figure not shown). As the result did not 


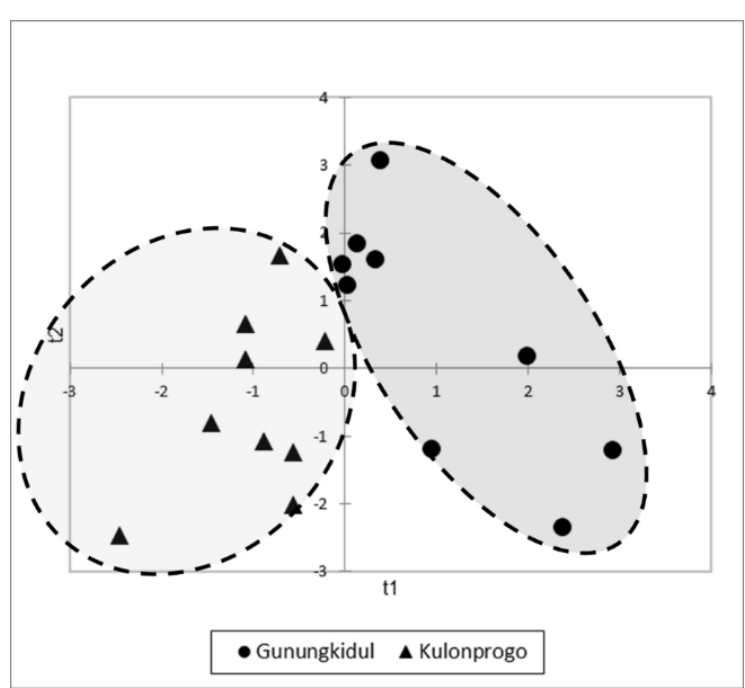

(a)

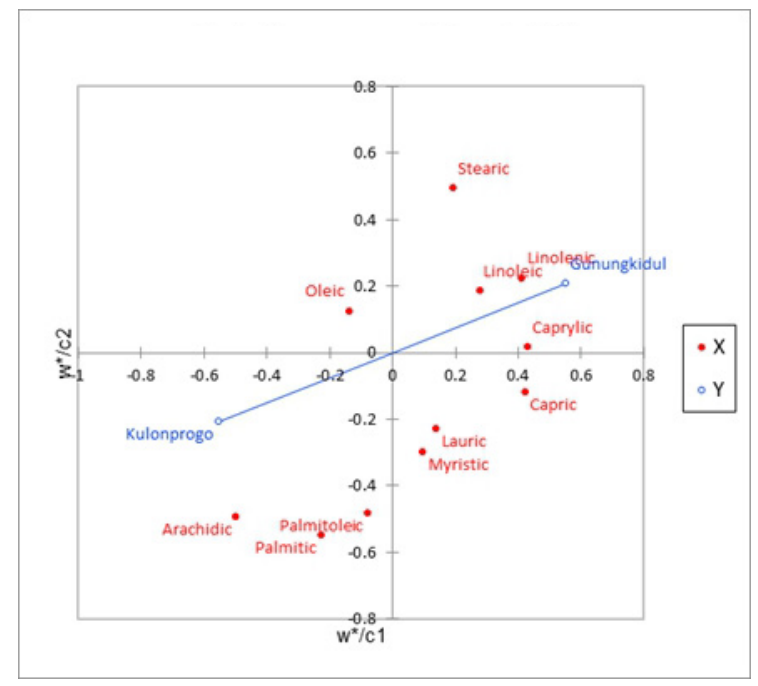

(b)

Figure 1. (a) Score plot of the PLS-DA model; (b) Loading plot of the PLS-DA model

showed a good clustering based on geographical origin, therefore, the use of multivariate analysis, such as PLS-DA, is performed. A supervised classification model was developed and evaluated by leave-one-out cross-validation to classify the cocoa samples based on origin (Jackknife LOO). Figure 1.a depicts the score plot of the PLS-DA model showing both sample origins. Each symbol, circle, and triangle represent the samples with varying origins. Two axes, score t1 and t2, represents two latent variables of the model, which were mathematically constructed and 'summed up' the fatty acid composition in this study. Complementing the previous figure, Figure 1.b depicts the loading plot of the PLS-DA model and shows how fatty acids composition $(X)$ relate to each other as well as to sample origins $(Y)$. Furthermore, the results of this study showed that cocoa bean samples from Gunungkidul could be distinguished from cocoa bean samples from Kulon Progo. Therefore, the ability of fatty acids to distinguish the geographical origin of cocoa beans shows that cocoa composition and fatty acid profile vary depending on geographic origin (Torres-Moreno et al., 2015).

\section{CONCLUSION}

The average composition of fatty acids from the Special Region of Yogyakarta (Patuk Gunungkidul and Kalibawang Kulon Progo) were dominated by stearic $(35.23 \%)$, oleic $(33.12 \%)$, and palmitic acids $(27 \%)$, respectively. The types and composition of fatty acids that can be used to distinguish the geographical origin of cocoa beans in the Special Region of Yogyakarta include unsaturated (palmitoleic, oleic, and linolenic acids) and saturated (capric, caprylic, and lauric acids) fatty acids. The three unsaturated fatty acids were significantly different in some origin regions of the cocoa bean sample, while the three types of saturated fatty acids were distinguishing factors due to their minimal availability in nature, as they were not detected in all regions. When applied with PLS-DA, the fatty acid composition can be used to distinguish the cocoa bean geographic origin in the Special Region of Yogyakarta.

\section{ACKNOWLEDGMENT}

The authors express their gratitude to farmers in Gunungkidul and Kulon Progo for collecting and preparing the cocoa bean samples. The authors are also grateful to the Faculty of Agricultural Technology Universitas Gadjah Mada and Yogyakarta Assessment Institute for Agricultural Technology for all of their support.

\section{CONFLICT OF INTERESTS}

The authors declare no conflict of interest.

\section{REFERENCES}

Acierno, V., Yener, S., Alewijn, M., Biasioli, F., \& Van Ruth, S. (2016). Factors contributing to the variation in the volatile composition of chocolate: Botanical and geographical origins of the cocoa beans, and brand- 
related formulation and processing. Food Research International, 84, 86-95. https://doi.org/10.1016/j. foodres.2016.03.022

Alam, N., Salim, M., \& Siswo, G. (2010). Cacao Fruit Characteristics Harvesting at Various Growth Location Abova Sea Level and Maturity Classes. 17(2), 123-130.

Aronhime, J. C., \& Garti, N. (1988). Solidification and Polimorphism in Cocoa Butter and the Blooming Problem Crystalization and Polimorphism of Fat And Fatty Acids. New York: Marcel Dekker, Inc.

Bertoldi, D., Barbero, A., Camin, F., Caligiani, A., \& Larcher, R. (2016). Multielemental fingerprinting and geographic traceability of Theobroma cacao beans and cocoa products. Food Control, 65, 46-53. https://doi. org/10.1016/j.foodcont.2016.01.013

Directorate General of Estate Crops. (2014). Pedoman Teknis Budidaya Kakao Yang Baik. Jakarta: Directorate General of Estate Crops, Ministry of Agriculture.

Directorate General of Estate Crops. (2016). Tree Crop Estate Statistics of Indonesian 2015. Jakarta: Directorate General of Estate Crops - Ministry of Agriculture.

Foubert, I., Vanrolleghem, P., Thas, O., \& Dewettinck, K. (2004). Influence of Chemical Composition on the Isothermal Cocoa Butter Crystallization. Journal of Food Science, 69(9), 471-477.

Fowler, M. S. (2009). Industrial Chocolate Manufacture and Use: Cocoa Beans: from Tree to Factory. In Industrial Chocolate Manufacture and Use: Fourth Edition. https:// doi.org/10.1002/9781444301588

Fraenkel, J.R, Wallen, N.E, Hyun, H. . (2012). How to Design and Evaluate Research in Education (8th ed.). New York: Mc Graw Hill.

Guehi, S. T., Dingkuhn, M., Cros, E., Fourny, G., Moulin, G., \& Vidal, A. C. (2008). Impact of cocoa processing technologies in free fatty acids formation in stored raw cocoa beans. Journal of Agricultural Research, 3(March), 174-179.

Isyanti, M., Sudibyo, A., Supriatna, D., \& Suherman, H. (2015). Penggunaan Berbagai Cocoa Butter Substitute ( CBS ) Hasil Hidrogenasi dalam Pembuatan Cokelat Batangan. 32(1), 33-44.

Jonfia-Essien, W. A., \& Tettey, E. (2016). Fat content and free fatty acid level of cocoa beans ( Theobroma cocoa ) relative to fermentation and storage periods. 58-61.

Kongor, J. E., Hinneh, M., de Walle, D. Van, Afoakwa, E. O., Boeckx, P., \& Dewettinck, K. (2016). Factors influencing quality variation in cocoa (Theobroma cacao) bean flavour profile - A review. Food Research International, 82, 4452. https://doi.org/10.1016/j.foodres.2016.01.012
Lehrian, D. W., Keeney, P. G., \& Butler, D. R. (1980). Triglyceride characteristics of cocoa butter from cacao fruit matured in a microclimate of elevated temperature1. Journal of the American Oil Chemists' Society, 57(2), 66-69. https://doi.org/10.1007/BF02674362

Liendo, R., Padilla, F., \& Quintana, A. (1997). Characterization of cocoa butter extracted from Criollo cultivars of Theobroma cacao L. Food Research International, 30(9), 727-731. https://doi.org/10.1016/S0963-9969(98)0002 5-8

Lipp, M., \& Anklam, E. (1998). Review of cocoa butter and alternative fats for use in chocolate-Part A. Compositional data. Food Chemistry, 62(1), 73-97. https://doi.org/10.1016/S0308-8146(97)00160-X

Liyanda, M., Karim, A., \& Yusya', A. (2012). Analysis of Land Suitability Criteria for Cocoa Production of Three Cluster Development in Pidie District. Jurnal Agrista, 16(2), 62-79.

McHenry, Lauren and Fritz, P. J. (1987). COCOA BUTTER BIOSYNTHESIS. The Metabolism, Structure, and Function of Plant Lipids, 337-338. https://doi.org/10.1007/9781-4684-5263-1

Minifie, B. W. (1989). Chocolate, cocoa, and confectionery: science and technology. New York: Van Nostrand Reinhold.

Mustiga, G. M., Morrissey, J., Stack, J. C., DuVal, A., Royaert, S., Jansen, J., ... Motamayor, J. C. (2019). Identification of Climate and Genetic Factors That Control Fat Content and Fatty Acid Composition of Theobroma cacao L. Beans. Frontiers in Plant Science, 10(October), 1-20. https://doi.org/10.3389/fpls.2019.01159

Park, P. W., \& Goins, R. E. (1994). In Situ Preparation of Fatty Acid Methyl Esters for Analysis of Fatty Acid Composition in Foods. Journal of Food Science, 59(6), 1262-1266. https://doi.org/10.1111/j.1365-2621.1994.tb14691.x

Ristanti, E., Suprapti, \& Anggraeni, D. (2016). Characteristics of Fatty Acid Cocoa Bean From 12 Regions of South Sulawesi. 15-22.

Saltini, R., Akkerman, R., \& Frosch, S. (2013). Optimizing chocolate production through traceability: A review of the influence of farming practices on cocoa bean quality. Food Control, 29(1), 167-187. https://doi.org/10.1016/j. foodcont.2012.05.054

Sirbu, D., Grimbs, A., Corno, M., Ullrich, M. S., \& Kuhnert, N. (2018). Variation of triacylglycerol profiles in unfermented and dried fermented cocoa beans of different origins. Food Research International, 111(April), 361-370. https://doi.org/10.1016/j.foodres.2018.05.025

Stéphanie Marty-Terrade and Alejandro G. Marangoni. (2012). Cocoa Butter and Related Compounds : Impact of Cocoa 
Butter Origin on Crystal Behavior. In Cocoa Butter and Related Compounds. https://doi.org/10.1016/C2015-002409-1

Tarigan, E.B.R., Towaha, J., Iflah, T., Pranowo, D. (2016). Substitution of Cocoa Butter with Hydrogenated Oil From Palm Kernel and Coconut for Milk Chocolate Product. Jurnal Littri, 22(4), 32-33.

Torres-Moreno, M., Torrescasana, E., Salas-Salvadó, J., \& Blanch, C. (2015). Nutritional composition and fatty acids profile in cocoa beans and chocolates with different geographical origin and processing conditions. Food Chemistry, 166, 125-132. https://doi.org/10.1016/j. foodchem.2014.05.141

Tresniawati, C., Yuniyati, N., \& Randriani, E. (2014). Penggunaan Marka Molekuler dalam Seleksi Genotipe Kako dengan Sifat Kadar Lemak Tinggi.
Tymoczko, John L, Berg, Jeremy M, Gatto, Gregory J, Stryer, L. (2015). Biochemistry.

Vieira, L. R., Efraim, P., Van De Walle, D., De Clercq, N., \& Dewettinck, K. (2015). Influence of Brazilian Geographic Region and Organic Agriculture on the Composition and Crystallization Properties of Cocoa Butter. JAOCS, Journal of the American Oil Chemists' Society, 92(1112), 1579-1592. https://doi.org/10.1007/s11746-0152728-y

Zyzelewicz, D., Budryn, G., Krysiak, W., Oracz, J., Nebesny, E., \& Bojczuk, M. (2014). Influence of roasting conditions on fatty acid composition and oxidative changes of cocoa butter extracted from cocoa bean of Forastero variety cultivated in Togo. Food Research International, 63, 328-343. https://doi.org/10.1016/j. foodres.2014.04.053 